\title{
PENGARUH SIMULATION METHOD TERHADAP KETERAMPILAN REMAJA TENTANG BANTUAN HIDUP DASAR DI DESA KEKAIT KECAMATAN GUNUNG SARI KABUPATEN LOMBOK BARAT TAHUN 2019
}

\author{
${ }^{1}$ Eka Rudy Purwana, ${ }^{2}$ Risa Erdian \\ 1,2 Jurusan Keperawatan Poltekkes Kemenkes Mataram
}

\begin{abstract}
Abstrak
Latar Belakang : Kondisi kegawatdaruratan dapat terjadi dimana saja, kapan saja dan sudah menjadi tugas dari petugas kesehatan untuk menangani masalah tersebut. Resusitasi Jantung Paru (RJP) merupakan bagian dari bantuan hidup dasar yang membatu jantung dapat berfungsi kembali sebagai pompa dan memperbaiki sirkulasi darah dalam tubuh. Bantuan Hidup Dasar dapat dilakukan oleh siapapun dan dimanapun sesegera mungkin disaat awal terjadinya henti jantung untuk meningkatkan angka kelangsungan hidup. Tujuan :Mengetahui pengaruh simulation method terhadap tingkat pengetahuan, sikap dan keterampilan remaja tentang Bantuan Hidup Dasar (BHD) Di Desa Kekait, Kecamatan Gunung Sari, Kabupaten Lombok Barat.Metode : Desain penelitian yang digunakan adalah pra experimental one group pretestposttest terhadap 21 responden dengan teknik sampling : purposive sampling. Pendidikan Kesehatan ini menggunakan teknik simulation method yang dilakukan selama 1 hari 60 menit . Pengumpulan data pengetahuan dan sikap menggunakan kuisioner, dan data keterampilan menggunakan checklist, dianalisis menggunakan Uji Wilcoxon Signed Rank Test dengan tingkat signifikasi $95 \%(\alpha=0.05)$.Hasil : Diperoleh hasil tersebut, simulation method tentang Bantuan Hidup Dasar (BHD) data keterampilan sebelum 71,4\% cukup sesudah 42,86\% baik,., dan keterampilan : $\rho=0,000)$.Kesimpulan : metode pendidikan kesehatan menggunakan simulation method berpengaruh terhadap peningkatan keterampilan pada remaja di Desa Kekait, Kecamatan Gunung Sari, Kabupaten Lombok Barat.

Saran : Melakukan tindakan Bantuan Hidup Dasar (BHD) secara mandiri di masyarakat untuk pertolongan pertama henti jantung.
\end{abstract}

Kata Kunci : Simulation Method, Keterampilan

\section{THE EFFECT OF SIMULATION METHOD ON SKILLS LEVEL TEENAGER ABOUT BASIC LIFE SUPPORT (BLS) AT KEKAIT VILLAGE, GUNUNG SARI SUB-DSTRICT, WEST LOMBOK IN 2019}

\begin{abstract}
Background : Emergency condition be able at everwhere and everytime and that is the task of healt workers to handle it. Cardiac Pulmonary Resucitation (CPR) is a part of Basic Life Support to helping Cardio refunction like pump and repair the circulation blood in body. Basic Life Support available do anyone and anywhere quickly at the beginning of cardiac arrest for contuinity live level. Puspose : to know the effect simulation method on knowledge, attitude, skills teenager about Basic Life Support (BLS) at Kekait Village, Gunung Sari Sub-dstrict, West Lombok District.Method : The desain of this research is pra experimental one group
\end{abstract}


pretest - posttest to 21 respondent with sampling : purposive sampling technique. Method of Health Education be used is simulation method technique which conducted for 1 day 60 minute. data collection of knowledge and attitude using questionnaire, and for a skills using checklist. The analyze with Wilcoxon Signed Rank Test with significance level is $95 \%(\alpha=0.05)$. Result: The result of this research, simulation method about Basic Life Support (BLS), attitude before 76,2\% negative after $62 \%$ positive, and skills before $71,4 \%$ enough after $42,86 \%$ good. Result (and skills : $\rho=0,000$ ). Conclusion: Health Education, simulation method influence the skills level of teenager about Basic Life Support (BLS) at Kekait Village, Gunung Sari, West Lombok.

\section{Key Word : Simulation Method, Skill.}

\section{PENDAHULUAN}

Kondisi kegawatdaruratan dapat terjadi dimana saja, kapan saja dan sudah menjadi tugas dari petugas kesehatan untuk menangani masalah tersebut. Walaupun begitu tidak menutup kemungkinan kondisi kegawatdaruratan dapat terjadi pada daerah yang sulit untuk membantu korban sebelum ditemukan oleh petugas kesehatan menjadi sangat penting (Sudiharto \& Sartono, 2011 dalam Erika Syliviana dkk, 2018). Setiap tahun, layanan gawat darurat medis mengkaji adanya lebih dari 420.000 cardiac arrest terjadi di luar rumah sakit di Amerika serikat dalam (American Heart Association, 2014 dalam Erika Syliviana dkk, 2018).Bila tidak segera mendapatkan bantuan, maka akan menimbulkan kematian secara mendadak pada orang yang mendapat serangan jantung (Black \& Hawk, 2005 dalam Mulyadi 2016). Pada tahun 2013 Layanan Medis Darurat atau Emergency Medical Service (EMS) di inggris berusaha menyadarkan sekitar 28.000 kasus out of hospital cardiac (OHCA) (British Heart Foundation, 2015 dalam Erika Syliviana dkk, 2018).Idealnya di dunia, semua orang akrab dengan teknik dasar pertolongan pertama dan mengambil pelatihan teratur untuk memastikan pengetahuan tetap berjalan. Menurut International Federation of Red Cross and Red Crescent Societies, (2011) dalam Erika Syliviana dkk, (2018). Menurut Riskesdas tahun 2018, Prevalensi penyakit jantung di Provinsi Nusa Tenggara Barat berdasarkan semua umur yaitu sebanyak 0,9\% yang didignosi dokter mengalami penyakit jantung (Riskesdas RI, 2018). Data prevalensi berbasis puskesmas usia yang mengalami penyakit jantung tahun 2017 pada usia 20 - 70 tahun keatas yaitu sebanyak 56 kasus di Kabupaten Lombok Barat (Dinas Kesehatan Provinsi NTB, 2018)

Resusitasi Jantung Paru (RJP) merupakan bagian dari bantuan hidup dasar yang membatu jantung dapat berfungsi kembali sebagai pompa dan memperbaiki sirkulasi darah dalam tubuh. Bantuan Hidup Dasar dapat dilakukan oleh siapapun dan dimanapun sesegera mungkin disaat awal terjadinya henti jantung untuk meningkatkan angka kelangsungan hidup. Maka itu pendidikan dan pelatihan tentang Bantuan Hidup Dasar (basic life support) penting diberikan kepada tim kesehatan sebagai penolong di pelayanan (Suharsono \& Ningsih, 2009 dalam 
Pangaribuan R. dkk, 2017)Salah satu upaya untuk meningkatkan pengetahuan adalah dengan pendidikan kesehatan. Pendidikan kesehatan merupakan upaya menerjemahkan apa yang telah diketahui tentang kesehatan kedalam perilaku yang di inginkan dari perorangan ataupun masyarakat melalui proses pendidikan (Pangaribuan R. dkk,2017) Pendapat Frame (2003) menyatakan bahwa bantuan hidup dasar (BHD) dapat diajarkan kepada siapa saja. Setiap orang dewasa seharusnya memiliki keterampilan BHD, bahkan anak-anak juga dapat diajarkan sesuai dengan kapasitasnya. Semua lapisan masyarakat seharusnya diajarkan tentang bantuan hidup dasar terlebih bagi para pekerja yang berkaitan dengan pemeberian pertolongan keselamatan (Resusitacion Council, 2010).

Metode pembelajaran yang akan digunakan dalam penelitian ini adalah menerapkan metode simulasi. Metode pembelajaran simulasi dapat menggambarkan keadaan sebenarnya dari suatu keadaan, penyederhanaan dari suatu fenomena di dunia nyata. Simulasi adalah suatu tiruan atau perbuatan berpura-pura saja Menurut Sunaryo (1989) dalam Wahyuni dan Baroroh (2012). Metode pembelajaran ini dipilih karena metode pembelajaran ini lebih menekankan pada keaktifan peserta didik dalam membangun konsep/pengetahuan yang dimiliki untuk mengatasi permasalahan yang dihadapi. Dalam pembelajaran ini, pendidik bersikap interaktif dalam pembelajaran dan menjadi fasilitator atau mediator dari lingkungan bagi peserta didik dalam pembelajaran. Penilaian proses pembelajaran merupakan bagian integral dalam pembelajaran, dilakukan melalui observasi terhadap unjuk kerja peserta didik, disamping dalam bentuk tes/ujian (Dandan Supratman: 2001 dalam Wahyuni dan Baroroh 2012) yang bertujuan untuk mengetahui Pengaruh Simulation Method Terhadap Keterampilan Remaja Tentang Bantuan Hidup Dasar (BHD) di Desa Kekait Kecamatan Gunung Sari Kabupaten Lombok Barat.

\section{METODE PENELITIAN}

Penelitian ini menggunakan desain penelitian pra experiment dengan rancangan one group pretest posttest. Pada desain ini tidak ada kelompok pembanding (control), tetapi paling tidak sudah dilakukan observasi pertama (pretest) yang memungkinkan menguji perubahanperubahan yang terjadi setelah adanya eksperimen (program). Bentuk rancangan ini adalah sebagai berikut. Teknik pengumpulan data yaitu, Data tentang karakteristik responden meliputi : inisial responden, umur, jenis kelamin, dan pendidikan dengan menggunakan kuisioner yang dibagikan kepada responden. Data pengetahuan remaja dalam melakukan Bantuan Hidup Dasar (BHD) diperoleh dengan menggunakan kuisioner yang dibagikan kepada responden.Data sikap remaja dalam melakukan Bantuan Hidup Dasar (BHD) diperoleh dengan menggunakan kuisioner yang dibagikan kepada responden.Data keterampilan remaja dalam melakukan 
Bantuan Hidup Dasar (BHD) diperoleh menggunakan alat bantu checklist. Data gambaran umum lokasi penelitian yaitu Desa Kekait, Kecamatan Gunung Sari, Kabupaten Lombok Barat didapatkan melalui studi dokumentasi dan melakukan penelusuran profil Desa Kekait, Kecamatan Gunung Sari, Kabupaten Lombok Barat. Analisa data dalam penelitian ini menggunakan SPSS (Statistical Product and Service Solution) dengan menguji hipotesis Uji Non Parametric yaitu Uji Wilocoxon Signed Rank Test untuk mengetahui perbedaan tingkat pengetahuan, sikap dan keterampilan sebelum dan sesudah diberikan pendidikan kesehatan tentang Bantuan Hidup Dasar (BHD) pada remaja dengan teknik simulation method dengan bantuan SPSS (Statistical Product and Service Solution) for windows release 16.0 dan taraf signifikan 95\% $(\alpha=0,05)$. Bila signifikasi $<0,05$, maka $H_{a}$ diterima, adanya pengaruh simulation method terhadap keterampilan remaja tentang Bantuan Hidup Dasar (BHD).

\section{HASIL PENELITIAN}

\section{Distribusi Responden Berdasarkan umur}

Tabel 1. Distribusi Responden Berdasarkan Umur di Desa Kekait Kecamatan Gunung Sari, Kabupaten Lombok Barat Bulan April 2019

\begin{tabular}{cccc}
\hline No & Umur & Jumlah & Persentase (\%) \\
\hline 1 & 18 & 7 & 33.3 \\
\hline 2 & 19 & 2 & 9.4 \\
\hline 3 & 20 & 4 & 19 \\
\hline 4 & 21 & 8 & 38.3 \\
\hline & Jumlah & $\mathbf{2 1}$ & $\mathbf{1 0 0}$
\end{tabular}

Berdasarkan tabel di atas menunjukkan bahwa jumlah responden terbanyak adalah berumur 21 tahun yaitu sebanyak 8 orang (38.3\%), dan jumlah terendah yaitu berumur 19 tahun sebanyak 2 orang $(9.4 \%)$.

\section{Distribusi Responden Berdasarkan Jenis Kelamin}

Tabel 2. Distribusi Responden Berdasarkan Jenis Kelamin di Desa Kekait Kecamatan Gunung Sari, Kabupaten Lombok Barat Bulan April 2019

\begin{tabular}{cccc}
\hline No & Jenis Kelamin & Jumlah & Persentase (\%) \\
\hline 1 & Laki - Laki & 13 & 62.0 \\
\hline 2 & Perempuan & 8 & 38,0 \\
\hline & Jumlah & $\mathbf{2 1}$ & $\mathbf{1 0 0}$
\end{tabular}

Berdasarkan tabel di atas menunjukkan bahwa jumlah responden terbanyak yaitu berjenis kelamin laki-laki sebanyak 13 orang (62\%), dan jumlah terendah yaitu berjenis kelamin perempuan sebanyak 8 orang (38\%). 


\section{Distribusi Responden Berdasarkan Tingkat Pendidikan}

Tabel 3. Distribusi Responden Berdasarkan Tingkat Pendidikan di Desa Kekait Kecamatan Gunung Sari, Kabupaten Lombok Barat Bulan April 2019

\begin{tabular}{cccc}
\hline No. & Tingkat Pendidikan & Jumlah & $\begin{array}{c}\text { Persentase } \\
(\boldsymbol{\%})\end{array}$ \\
\hline $\mathbf{1}$ & $\mathbf{2}$ & $\mathbf{3}$ & $\mathbf{4}$ \\
\hline 1 & SMA/SMK/Sederajat & 7 & 33.3 \\
\hline $\mathbf{1}$ & $\mathbf{2}$ & $\mathbf{3}$ & $\mathbf{4}$ \\
\hline 2 & Perguruan Tinggi & 14 & 66.7 \\
\hline & Jumlah & $\mathbf{2 1}$ & $\mathbf{1 0 0}$ \\
\hline
\end{tabular}

Berdasarkan tabel di atas menunjukkan bahwa jumlah responden terbanyak adalah responden yang berpendidikan Perguruan Tinggi berjumlah 14 orang $(66.7 \%)$ dan yang terendah adalah responden yang berpendidikan SMA/SMK/Sederajat yaitu berjumlah 7 responden $(33.3 \%)$.

\section{Keterampilan Responden Sebelum Dilakukan Simulation Method Tentang Bantuan} Hidup Dasar (BHD)

Tabel 4. Distribusi Keterampilan responden sebelum dilakukan Simulation Method tentang Bantuan Hidup Dasar (BHD) Di Desa Kekait, Kecamatan Gunung Sari, Kabupaten Lombok Barat Bulan April 2019

\begin{tabular}{cccc}
\hline No. & Keterampilan & Jumlah & Persentase (\%) \\
\hline 1 & Baik & 1 & 4.8 \\
\hline 2 & Sedang & 15 & 71.4 \\
\hline 3 & Kurang & 5 & 23.8 \\
\hline & Jumlah & $\mathbf{2 1}$ & $\mathbf{1 0 0}$ \\
\hline
\end{tabular}

Berdasarkan di atas menunjukkan bahwa sebagian besar keterampilan remaja tentang Bantuan Hidup Dasar (BHD) termasuk kategori sedang sebanyak 15 orang (71.4\%), dan yang paling sedikit termasuk kategori baik sebanyak 1 orang (4.76\%) 
5. Keterampilan Responden Setelah Dilakukan Simulation Method Tentang Bantuan Hidup Dasar (BHD)

Tabel 5. Distribusi Keterampilan responden sesudah dilakukan Simulation Method tentang Bantuan Hidup Dasar (BHD) Di Desa Kekait, Kecamatan Gunung Sari, Kabupaten Lombok Barat Bulan April 2019

\begin{tabular}{cccc}
\hline No. & Keterampilan & Jumlah & Persentase (\%) \\
\hline 1 & Baik & 9 & 42.8 \\
\hline 2 & Sedang & 8 & 38 \\
\hline 3 & Kurang & 4 & 19.2 \\
\hline & Jumlah & $\mathbf{2 1}$ & $\mathbf{1 0 0}$ \\
\hline
\end{tabular}

Berdasarkan Tabel 9 di atas menunjukkan bahwa sebagian besar keterampilan remaja tentang Bantuan Hidup Dasar (BHD) termasuk kategori baik sebanyak 9 orang (42,9\%), dan yang paling sedikit termasuk kategori kurang sebanyak 4 orang (19.2\%)

6. Pengaruh Simulation Method Terhadap Keterampilan Responden Tentang Bantuan Hidup Dasar Di Desa Kekait Kecamatan Gunung Sari Kabupaten Lombok Barat.

Tabel 6. Analisis Pengaruh Simulation Method terhadap keterampilan responden tentang Bantuan Hidup Dasar (BHD) Di Desa Kekait, Kecamatan Gunung Sari, Kabupaten Lombok Barat Bulan April 2019

\begin{tabular}{|c|c|c|c|c|c|c|}
\hline \multirow{2}{*}{ No. } & \multirow{2}{*}{ Keterampilan } & \multicolumn{2}{|c|}{ Pre } & \multicolumn{2}{|c|}{ Post } & \multirow[t]{2}{*}{$\rho$} \\
\hline & & $\mathbf{n}$ & $\%$ & n & $\%$ & \\
\hline 1 & Baik & 1 & 4.76 & 9 & 42.86 & \multirow{4}{*}{$\mathbf{0 , 0 0 0}$} \\
\hline 2 & Sedang & 15 & 71.4 & 8 & 38.09 & \\
\hline 3 & Kurang & 5 & 23.84 & 4 & 19.05 & \\
\hline & Total & 21 & 100 & 21 & 100 & \\
\hline
\end{tabular}

Hasil statistic menggunkanan Uji Non Parametric yaitu Uji Wilcoxon Signed Rank Test untuk Pendidikan Kesehatan menggunakan Simulation Method terhadap keterampilan remaja tentang Bantuan Hidup Dasar (BHD) di peroleh $\rho$ adalah 0,000 atau nilai $\rho(0,000)$ $<\alpha(0,05)$ yang berarti hipotesis nol $\left(\mathrm{H}_{0}\right)$ ditolak atau hipotesis kerja $\left(\mathrm{H}_{\mathrm{a}}\right)$ diterima, yang artinya metode pendidikan kesehatan menggunakan Simulation Method tentang Bantuan Hidup Dasar (BHD) berpengaruh terhadap peningkatan keterampilan remaja. 


\section{PEMBAHASAN}

\section{A. Pengaruh Simulation Method terhadap Keterampilan Remaja tentang Bantuan Hidup Dasar (BHD) di Desa Kekait Kecamatan Gunung Sari}

Berdasarkan hasil keterampilan remaja sebelum diberikan pendidikan kesehatan tentang Bantuan Hidup Dasar (BHD) terdapat kriteria terbanyak yaitu sebanyak 15 responden $(71,4 \%)$ keterampilannya sedang.Berdasarkan hasil keterampilan remaja setelah diberikan pendidikan kesehatan tentang Bantuan Hidup Dasar (BHD) terdapat kriteria terbanyak yaitu sebanyak 9 responden $(42,86 \%)$ keterampilannya baik. Dalam proses pendidikan atau pelatihan, Notoatmodjo (1993 : $53-55$ dalam Soekirko 2007) menyebutkan bahwa suatu sikap belum tentu terwujud dalam praktek atau tindakan. Masih diperlukan kondisi tertentu yang memungkinkan terjadinya perubahan sikap menjadi praktek.Dalam penelitian Chaundary, dkk (2011) dalam Umi Nur Hasanah,dkk (2015) menyatakan bahwa terjadi peningkatan keterampilan RJP dapat dilakukan dengan cara mengikuti pelatihan BHD pelatihan yang berkesinambungan diperlukan untuk menyegarkan kembali pengetahuan dan keterampilan. Dari hasil pengamatan peneliti dan berdasarkan urutan prosedur langkah - langkah Bantuan Hidup Dasar (BHD) ditemukan bahwa keterampilan responden sedang namun untuk prosedur atau langkah - langkah responden masih belum sesuai dengan prosedurnya. Dari hasil pengamatan responden sebagian besar langsung melakukan bantuan nafas buatan tanpa dan langsung menghubungi tenaga medis terdekat. Selain itu responden juga belum paham tentang arti dari langkah - langkah atau prosedur yang di berikan.

\section{KESIMPULAN}

Berdasarkan hasil penelitian dan pembahasan, maka peneliti mengambil kesimpulan sebagai berikut. Keterampilan remaja tentang Bantuan Hidup Dasar (BHD) sebelum dilakukan pendidikan kesehatan di Desa Kekait Kecamatan Gunung Sari Kabupaten Lombok Barat sebagian besar termasuk kategori sedang. Keterampilan remaja tentang Bantuan Hidup Dasar (BHD) sesudah dilakukan pendidikan kesehatan di Desa Kekait Kecamatan Gunung Sari Kabupaten Lombok Barat sebagian besar termasuk kategori baik.Ada pengaruh Pendidikan kesehatan menggunakan simulation method terhadap tingkat pengetahuan, sikap, dan keterampilan remaja tentang Bantuan Hidup Dasar (BHD) di Desa Kekait Kecamatan Gunung Sari Kabupaten Lombok Barat ( $\rho=0,000$ ).

\section{DAFTAR PUSTAKA}

A. Wawan, Dewi. M. 2010. Teori Pengukuran Pengetahuan, Sikap dan Perilaku Manusia. Yogyakarta : Nuha Medika.

American Heart Association. 2015. "Fokus Utama Pembaruan Pedoman American Heart Association 2015 untuk CPR dan EGC". Tersedia dalam : https://eccguidelines.heart.org. Diakses pada oktober 2018. 
Badan Penelitian Dan Pengembangan Kesehatan Kementrian Kesehatan Republik Indonesia. 2018. Riset Kesehatan Dasar ; RISKESDAS 2018. Jakarta : Balitbang Kemenkes RI. hal 79.

Dinas Kesehatan Provinsi Nusa Tenggara Barat. 2018.Profil Kesehatan Provinsi Nusa Tenggara Barat 2018. Mataram : Dikes Provinsi NTB.

Mulyadi. 2016. “Pengaruh Penyuluhan dan Simulasi Bantuan Hidup Dasar (BHD) Terhadap Tingkat Pengetahuan Siswa SMAN 9 Kota Manado".. Tersedia dalam : http://ejournal.stikimmanuel.ac.id. Diakses pada oktober 2018.

Notoatmodjo, S. 2007. Promosi Kesehatan dan Ilmu Perilaku. Jakarta: Rineka Cipta.

Nur Hasanah, Umi. 2015. “ Hubungan Tingkat Pengetahuan dengan Keterampilan Perawat dalam Melakukan Tindakan Bantuan Hidup Dasar (BHD) DIi RSUD Kabupaten Karanganyar”. Tersedia dalam : http://digilib.stikeskusumahusada.ac.id. Diakses pada oktober 2018.

Pangaribuan. Resmi, dkk. 2017. “ Pengaruh Media Pendidikan Kesehatan Terhadap Pengetahuan Bantuan Hidup Dasar (BHD) (Studi Eksperimen Pada Perawat Pelaksana di Rumah Sakit TK. II Putri Hijau Medan Tahun 2017)" JUMANTIK Volume 3, No. 1. Tersedia Dalam : http://jurnal.uinsu.ac.id. Diakses pada oktober 2018.

Wahyuni, Daru dan Kiromim Baroroh. 2012. "Penerapan Metode Pembelajaran Simulasi Untuk Meningkatkan Aktivitas Dan Prestasi Belajar Ekonomika Mikro" Yogyakarta : Jurnal Ekonomi dan Pendidikan, Vol. 9 No. 1. Tersedia dalam : https://media.neliti.com. Diakses pada oktober 2018. 